\title{
Journeys from the East: The Popular Geopolitics of Film Motivated Chinese Tourism
}

\begin{abstract}
Over the past five years the number of outbound travellers from the People's Republic of China (PRC) doubled, making Chinese tourists the largest group of international travellers in the world. Fuelled by the strength of the Renminbi, this Chinese tourism 'boom' has been generated by a growing number of wealthy Chinese urbanites with an appetite for overseas travel. Chinese tourists now outspend all other international travellers with tourism receipts totalling $\$ 261$ billion in 2016 alone (UNWTO 2017). Drawing on media reports of the impact of box office hits on Chinese outbound tourism, we argue that popular cinema shapes Chinese imaginaries of travel, which impact on the everyday geopolitics of Sino-host tourism encounters. Through a critical discourse analysis of representations of Chinese tourism practices in Chinese film, we highlight key visual and narrative tropes of economic and political power that present touristic practices as imaginable, aspirational, and attainable. Yet actual tourism encounters often play out differently than their onscreen imaginaries. Drawing on theoretical and methodological insights from Film Studies and political anthropology and geography, this article contributes to emerging multidisciplinary work on how filmic representations of the economic influence of the Chinese tourism market globally mediates ongoing rearticulations of the geopolitics of China within what has been widely dubbed the "Chinese Century".
\end{abstract}




\section{Introduction}

Between 2001 and 2016, the number of international Chinese tourists more than doubled, and today, more than one out of every 10 travellers globally is a Chinese national (Arlt, 2016). In 2015, international Chinese tourists exceeded 135 million, with tourism receipts exceeding US \$261 billion, making China by far the largest single source market in terms of total trips and spending (Arlt, 2016). The growth of the Chinese market is in part the result of aggressive government campaigns to diversify the economy and increase consumer spending. Initiatives such as the development of new airports and reduced travel restrictions have contributed to this growth, while the Chinese film industry crafts depictions of tourism as aspirational and achievable. A number of locations within Asia that have featured in popular Chinese films are experiencing widespread economic benefits (Arlt 2016). As a recent commentator for Forbes Asia predicts, in terms of “Chinese outbound tourism - You ain't seen nothin' yet!" [Arlt, (2016)]. This paper investigates how popular cinema mediates this tourism boom and theorizes its broader geopolitical implications.

Chinese tourists abroad have been valued for their economic contributions to tourism economies, and heavily criticized for their behaviour abroad. Yet, social and popular media, as well as ethnographic materials, demonstrate the sometimes ambivalent sentiments directed towards Chinese tourists by members of host countries. The Chinese tourism market often draws upon recurrent discourses of what it means to be a modern and mobile middle-upper class Chinese citizen. While films often depict protagonists passing relatively easily through tourist spaces and host countries, these depictions are not always realized by Chinese tourists abroad, who have been the subject of international critique. While the structuring devices of classical narrative cinema, such as the happy ending, dictate that problems are overcome by the end of the 
feature film, this is not the experience of many Chinese tourists and the hosts they encounter. This gap between Chinese tourism as imagined in Chinese cinema, and as represented in international news media presents an opportunity for methodological intervention in how we think about the role and relationship between film and tourism in Chinese geopolitics.

Film plays a powerful mediating role in the Sino-host tourist encounter, where travel is linked to ideas of modernity. Beyond representation, 'Film and television act as maps for the everyday social cultural and geopolitical imaginaries and realities of everyday life' [Lukinbeal, (2004), p. 247]. They are both reflective of and reflect 'cognitive maps of a geopolitical imaginary' (Jameson, 1995) affording a multiscalar form of identity and meaning creation (Bruno, 2002). Cinematic narratives co-construct the geopolitical world and national identities, and provide explanatory narratives during periods of political anxiety (Power and Crampton, 2005). Film is a discursive formation that plays a critical role in the globalization and commoditization of culture. It is a modernizing device, where shared meanings and identity formations become increasingly embedded in social worlds.

The central role of television series and films in informing migratory imaginaries, both in China and among the Chinese-speaking diaspora, has been well documented (Sun 2002; Lewis, Martin, and Sun 2016). Yet, with the exception of some earlier accounts of domestic tourism in China (Nyiri 2006), there are few studies connecting film-texts to the recent boom in Chinese tourism.

In this paper, we argue that the disjunctures between the 'reel' and 'real' mirror wider geopolitical tensions, between a Chinese desire to be universally recognised as 'modern' and the everyday ways this desire is enacted and resisted in tourism in the Asia-Pacific. In this way, we illustrate how middle-upper class Chinese modernity is allegorized in film through widespread 
depictions of structurally and generically crafted scenes that present travel as both aspirational and achievable. These depictions are not always borne out in real life encounters in tourism that are often rife with interpersonal challenges. This narrative of difficult encounters frequently feeds back into film content, but is often ameliorated in the typical happy ending of classical narrative cinema. Thus, we illustrate how popular cinema shapes Chinese imaginaries of travel, which impact the everyday geopolitics of Sino-host tourism encounters.

Our analysis illustrates the friction between film-based imaginaries and receiving countries' imaginaries of Chinese tourists — or between the real-reel and Chinese cosmopolitanism on film, in contrast to border and behaviour campaigns. We elaborate on this argument through a critical discourse analysis of three Chinese films; If You are the One (Feicheng wurao, dir. Feng Xiaogang, 2008), Finding Mr. Right (Bei jing yu shang xi ta yu, dir. Xue Xiaolu, 2013) and Lost in Thailand (Ren Zai Jiong Tu zhi Tai Jiong, Xu Zheng, 2012). Collectively, these films present an image of the Chinese tourist as cosmopolitan citizen, able to blend and adapt to surroundings which in turn adapts to accommodate the protagonist. By contrast, media representations and ethnographic observations of actual Chinese touristic practices and responses to these, paint a very different picture. Thus, we develop a critical discourse analysis of the real-reel in popular geopolitics and tourism (Lukinbeal, 2012).

\section{Travel on film}

Early cinema was used to make disparate geographical areas visible to one another, as cameramen from both Thomas Edison's association and the Lumière brothers' laboratories travelled overseas to film such exotic sights as Japanese sword fighting and geisha dance performances. Cinema content was shaped by travel in this way. Film historians further argue 
that travel practices also shaped the form of early cinema, citing the widespread development of railway systems as a factor in the invention of cinema itself (Carlin 2007; Kirby 1997: 42-48; Schivelbusch 1986: 160).

As the number of rapidly militarizing nations around the globe began to take cinema apparatus to war, film quickly became a propaganda tool, used to create an idealized image of the nation designed for viewing by other nationalities and peoples. Around this time, film theorists such as Béla Bàlazs, Vachel Lindsay, Ricciotto Canuda, and Louis Delluc began to develop an idea of popular cinema as a 'universal language' (Carter 2010, p. xxiv). The rapid development of propaganda film practices would appear to confirm this potential, as nations used the apparatus to communicate visually with mass audiences in other parts of the world. At the same time, the cinema made domestic audiences visible to themselves (Hansen 2000), participating in the creation of a mass public that both consumed images of other national publics, and defined itself against the knowledge of others acquired through film viewing. While few believe that the universal language or 'cinematic Esperanto' imagined by $\mathrm{Xu}$ Chi (Bao 2009, 143) has been achieved (Hansen 1985, Frey 2010), international co-production and global distribution practices have created some common understandings and expectations about cinema form and content. Genre, defined by Steve Neale as encompassing industrial and audience expectation, contribution to a generic corpus and the rules or norms by which a genre film must abide $(1990,56)$, would appear to be one such area of common understanding. For Neale, 'genres are instances of repetition and difference' $(1980,51)$, and so stock genres such as the romance can bear some degree of national specificity while remaining legible across nations. Yet as Tess Dwyer (2015) argues, films that draw on universally-understood forms like the romance genre often obscure the difficulties of communication across cultures. Contrasting 
'polyglot films' 'marked by the naturalistic presence of two or more languages at the level of dialogue and narrative' [2005: 296] with films that rely on cultural stereotype, Dwyer argues that the polyglot genre 'exposes one of the cinema's founding myths: that it speaks a universal language' (2005: 297). Despite featuring multiple languages, the films analyzed in this paper largely elide the difficulties of translation, focusing instead on intercultural understanding, and in this way, because a mechanism of soft power strategies (Nye, 2004). In this way, this recent wave of Chinese tourist cinema presents intercultural understanding through tourism as an attainable, as well as desirable practice that often overshadows historical, political and economic contexts. Yet a number of concurrent geopolitical discourses reporting on these representations suggest otherwise.

\section{Mobility in and from China}

The touristic practices depicted in this new wave of travel cinema reflect a dominant discourse in China relating travel to the way people are valued. Since the opening and reform policies (Gaige Kaifang) of the early 1980s, a major social and political directive of the Chinese Communist Party (CCP) has been to reposition the People's Republic of China as a major global player. These reforms have been premised on enabling and channelling the movement of people, capital, and commodities in and out of China. The CCP's cultural authority has been largely premised on their ability to realize social and spatial mobility (Xiang 2007, 2003, Nyiri 2001, 2006, 2010). Before passports were reintroduced in 1985, PRC citizens could only travel overseas on student exchanges and special bilateral arrangements. Since the 1990s a 'leaving country fever' has (chuguo re) ensued. Tourism has grown exponentially over the past 10 years, with the 40.9 million Chinese tourists recorded in 2007 more than tripling by 2016 (World Bank 
2016). These mobilities are symptomatic of wider imaginaries that have captured the attention of the Chinese-speaking public.

As Julie Chu argues, mobility has become a 'qualisign' of the modern Chinese subject (Chu 2010). Charles Peirce defines 'qualisigns' as 'certain embodied qualities that are components of a given intersubjective spacetime ... whose positive or negative value they signify' (1998:16). Drawing on Peirce, Chu demonstrates the central subject-forming role of mobility as a practice. Chinese images of, and desire for, mobility have become powerfully embodied subjectivities (Fong 2006; Fong 2011; Friedman and Mahdavi 2015; Friedman 2015; Jacka 2014; Jacka and Gaetano 2004; Lewis, Martin, and Sun 2016; Liu-Farrer 2011; Ong 1997; Sun 2002; Yeoh and Lin 2013). We take inspiration from Chu's use of the term 'qualisign' which allows us to think through the alternate ways mobility is embodied not only in human movements, but also in the movement of material cultures, and indeed the moving image. Thus, we consider how mobility as a qualisign of the modern Chinese subject interacts with film texts and mediates contemporary popular geopolitics of Chinese tourism.

\section{Popular geopolitics of film-induced tourism}

Tuathail and Agnew (1992) have argued that the "Geopolitical ... is an innately political process of representation by which the intellectuals of statecraft designate a world and 'fill' it with certain dramas, subjects, histories and dilemmas" [Tuathail \& Agnew, (1992), p. 194]. Everyday and state level geopolitical practices are often constructed through simplified geographical understandings of place and 'ready-made geographically-infused reasoning'

(Tuathail \& Agnew, 1992: 191). Over the last two decades, scholars of critical geopolitics have expanded the field to encompass a broad range of popular discourse and visual culture (Dalby, 
2010: 280). We build on these theoretical insights in critical and popular geopolitics to examine film-induced tourism in China (Hansen, 1993; Law, Bunnell, \& Ong, 2007).

Film-induced tourism co-constitutes tourism imaginaries of and in place. The intertextuality of these encounters are significant points of departure for scholars of popular geopolitics who are increasingly concerned with the relationship between texts and bodily experience (Carter \& McCormack, 2006; Dodds, 2005). For instance, Dittmer and Gray highlight how '[c]entral to the development of critical geopolitics has been the recognition of geopolitics as something everyday that occurs outside of academic and policymaking discourse' (Dittmer \& Gray, 2010, p. 1667). Thus, scholars of popular geopolitics examine how geopolitical reasoning is mapped out through a range of popular media such as film, novels, and board games. From a popular geopolitics perspective, the film-tourism connection is perhaps unsurprising given the recursive relationship between space, place and popular discourse.

Films are 'intimately connected to the formation of new geographical imaginations and in this sense their imagery formed a kind of geopolitical world' (Power \& Crampton, 2005, p. 194). They create new geographical imaginaries of space, which are multiplied by the corollary reviews, commentaries, and responses to the film. Increasingly, these conversations also describe how films mediate everyday tourism encounters as well as how they impact the cultures, economies, and environments of places through the influx or decline of tourists (Mostafanezhad and Promburom, 2016).

In what follows, we draw on a discourse analysis of three films depicting Chinese tourism abroad including If You are the One, Finding Mr. Right and Lost in Thailand. Our main argument is developed from our analysis of popular media reports of Chinese film-induced tourism in Japan, the U.S. and Thailand. We used convenience sampling of online popular media 
reports including news articles, commentaries and film reviews of international Chinese filminduced tourism (Gee, 2014). We pay close attention to film related texts that depicted the 'consequences/reactions' to the films examined. Recurrent themes in popular media texts were identified and used to develop key insights into the geopolitics of film tourism. We approach film as a reflection of broader circuits of discourse in popular culture that demonstrate widely held sentiments around Sino-host tourism encounters and the real-reel in popular geopolitics and tourism (Lukinbeal, 2012).

\section{If You are the One}

After the PRC opened its doors to global popular culture in the 1980s, mainland audiences came to rely on Hong Kong and Japanese productions. Today a much more diverse array of media flows into China, from the 'Korean Wave' (hanliu) to Hollywood co-productions (Kōichi Iwabuchi, Muecke, and Thomas 2004; Pease 2009), and China itself has become a media production powerhouse. Yet, Japan still holds a unique position within the imaginaries of many Chinese consumers, particularly in terms of tourism. For example, a study conducted at Nagoya University in 2014 with 115 Chinese tourists quoted several films and TV shows as shaping the reasons why they chose particular destinations (JT 2015). The popularity of the 2008 box office hit If You Are the One was credited with influencing Chinese tourists' decisions to visit Hokkaido, Japan's northernmost island.

If You are the One ranked second in the box office listings for China in 2008, earning over 53 million US dollars (Box Office Mojo 2017). Since the release of If You are the One there has also been a popular dating game show airing from 2010 that uses the same title. There is no connection between the two, save for the original Chinese titles' connotations of romantic fatalism. The film is a romantic comedy following Qin Fen (played by famous Beijing comedian 
Geyou), who falls upon a small fortune and decides to start dating via online advertisements. After a series of unfortunate dates, Qin Fen meets Xiaoxiao (played by Taiwanese actress Shuqi), who seeks distraction from her complicated relationship with a married man. After striking up a friendship with Qin Fen, Xiaoxiao asks him to become her boyfriend, even though she is still in love with her former partner. He accepts and to consecrate their new relationship, they travel to Hokkaido to visit the sites where she had once travelled with her former lover, and to see a friend of Qin Fen's who had migrated to Japan years ago.

Mainland Chinese visitors to Japan grew from 942,439 in 2007 to over 6.3 million in 2016, making them Japan's fastest growing market. Chinese consumers have spent roughly 12.2 billion US, around 41 percent of all international tourism consumption in Japan in 2015 (MLIT 2017). The popularity and ferocity of this shopping practice birthed a new term in the Japanese media, bakugai, which literally means 'explosive shopping'. Yet Japan's appeal extends beyond its weak yen and shopping opportunities; official surveys conducted among Chinese tourists have consistently shown that Japan's natural beauty and activities such as cherry blossom viewing and hot springs are ranked above shopping (see for example JNTO 2015; METI 2015).

If You Are the One embodies many of the idealised tales of mobility in contemporary China. In the late 90 s and early 2000s, migration was a central obsession in Chinese popular discourse (Sun 2002; Ong 1997). What originally was a positive image of migration has lost its lustre and is now presented in far more complicated terms these days (Lewis, Martin, and Sun 2016). The mobilities that are considered desirable today are less likely to be long-term, and more predictably depict the cosmopolitanizing effects of shorter mobilities, such as study abroad or tourism (Nyiri 2006, 2010). Qin Fen, a former migrant who catered to tourists, now finds himself enjoying the fruits of his life of mobility by exploring picturesque settings with beautiful 
women. He epitomises the complex connections between morality and consumerist cosmopolitanism that define idealised masculinity in China today (Osburg 2013; Song and Lee 2010).

The chronology of the various settings of If You Are the One is symptomatic of the popular geopolitics of China's relationship with its neighbours, depicted through the eyes of the modern Chinese subject. The film juxtaposes the classy interiors of Beijing's Houhai district, the lush greenery of Hangzhou, and the expansive landscape of Hokkaido's seaside. The characters are established as urban elites in Beijing, who are confronted with their past while on tour in the historical scenery of Hangzhou, and then later transformed in Japan. Classical music and tearooms are contrasted with scenes of rice paddies and the watery landscape of Hangzhou, an elegiac reference to an imagined Chinese past that resembles classical paintings and period dramas. Within this setting, Xiaoxiao faces her married lover and decides on a path to move ahead. Once in Japan, references to Xiaoxiao's past and Japan's past are used to present possible futures in Hokkaido. The trip to Hokkaido consecrates their new arrangement, and Qin Fen is reunited with an old friend. Japan is depicted as a destination that allows images of tradition to be neatly combined with the future.

Although often framed in sarcastic terms, If You Are the One repeatedly depicts Japan as a quasi-mystical and reflexive space where past and future destinies fold onto one another. Qin Fen is obsessed with stopping at various religious sites and buildings in Hokkaido. He exhausts a catholic priest in efforts to atone for his sins, and interrupts a yakuza funeral to give thanks to Buddha in a temple. Qin Fen states that he has developed faith since meeting Xiaoxiao, and that 'Hokkaido is a sacred place' for him. Hokkaido's reflexive qualities are also constructed in imagistic terms through long shots of both Qin Fen and Xiaoxiao reflecting on life while gazing 
across Hokkaido's landscape. Other tropes include an intimate moment drinking with Japanese locals where the song Shiretoko Ryojō (The Mood of Traveling in Shiretoko Peninsula) is introduced as a motif that will be repeated as each character consider their life changes later in the film. A classic Showa period song released in 1965, Shiretoko Ryojo contrasts the intoxicating qualities of travel with the pain of leaving. A similarly nostalgic mood is created through the use of Japanese clothing such as yukata. Xiaoxiao wears a luxurious kimono before undressing for a hot spring bath during a scene in which she attempts suicide.

If You Are the One is suggestive of Julie Chu's 'politics of destination' (2010), where the desire for mobility is entangled with cosmological considerations of selfhood and the future. In this sense, movement and aspiration take on religious overtones for the modern Chinese subject. Travel to and within Japan is positioned firmly within the romance genre in this film, connecting touristic imaginaries to romantic aspirations, and to the pilgrimage-style goal of becoming a better person. The characters develop through travel by working through personal issues and forming a religious approach to self-improvement. Romance, desire, and personal achievement are also key concerns in the US-based Finding Mr Right.

\section{Finding Mr. Right}

Desire, both in terms of aspirational ideals for the future and in terms of romance, similarly permeates Finding Mr Right. This unusual romantic comedy tells the story of "birth tourism," a recently controversial form of tourism from China to the USA. Birth tourism has seen an increasing number of Chinese women temporarily migrate to the USA to give birth in American hospitals and practice yuezi, the month of recovery recommended to post-partum women in China. Women, both with and without their partners, travel to give birth in order to obtain a US passport for their babies, some hoping that their child, once grown, can petition the 
US government for a visa for their parent(s) in return. Before 2015, many mothers also chose to give birth in the US to avoid the high fines payable in China for violating the one child policy. Since the relaxation of this policy however, 'birth tourism' numbers continue to grow (Shyong 2016). Industry publications estimated a total of 60,000 for 2014, a sixfold increase since 2012 . While birth tourism is technically legal, many opponents of the recent surge claim that women who buy 'birthing packages' from US-based companies are being instructed to lie to immigration officials. In 2015, Senator David Vitter introduced legislation to end birthright citizenship, calling the practice of birth tourism 'illegal' (Sheehan 2015). Jon Feere at the Center for Immigration Studies similarly argued before the US Congress that birth tourism 'represents a major abuse of immigration law' (Sheehan 2015).

In China however, the practice remains well-known and relatively aspirational, with key media figures rumored to have given birth to their children in the US. China's CCTV channel featured a programme dedicated to the phenomenon in 2014, sending reporters out to the streets of Beijing to discover that 80 per cent of respondents had heard of or personally knew people who had travelled abroad to give birth ( $\mathrm{Lu} 2014)$. The same channel addressed the role of the hit film Finding Mr. Right in popularizing the topic. Finding Mr. Right made more than 82 million US dollars in China, and was the ninth-highest-earning domestic film of 2013 (Shyong 2016). Noting that the film was marketed as a response or updated version of Sleepless in Seattle (Nora Ephron, 1993, TriStar Pictures), CCTV hosted a live broadcast from the US city on New Year's Eve 2013. CCTV correspondent Qi Gao commented on the number of Chinese tourists inspired to travel to Seattle by the film, suggesting that 'for the young generation of Chinese, it's not just for a destiny of traveling, it's for a destiny of romance' (Cohen 2013). 
While the movie was mostly filmed in British Columbia, New York, and Beijing, references to Sleepless in Seattle run through the plot and dialogue transforming this story of quasi-legal and extremely risky touristic practice into a heart-warming romance. Protagonist Jia Jia (Tang Wei) wraps a concealing strap around her pregnant belly in a short montage showing her arrival at the airport, suggesting she intends to conceal her pregnancy from the immigration officer on duty. We see the same officer summarily reject the request for a two-week visa from the man ahead of her in line. Jia Jia struggles to communicate in English and to convince the immigration officer to grant her a six-month visa. Drawing on popular culture discourses, Jia Jia replies to the officer's questioning of her marital status with a short rendition of Beyonce's 'All the Single Ladies.' When asked about her interest in visiting Seattle, she declares "Sleepless in Seattle - I love that movie!". In this way, Jia Jia demonstrates her ability to perform as a 'good' tourist by showing familiarity with a shared lexicon of popular culture.

The Seattle we see through her eyes is more glamorous than Meg Ryan's earlier version, as she trades the Target stores frequented by expecting Chinese mothers both on- and off-screen for designer stores and five-star hotels. Jia Jia's spending spree is suggestive of the consumption boom driving Chinese tourists to an average of $\$ 1,783$ while visiting the US in 2016 (Fung Global Retail and Tech, 2016).

What these observations point to is a cultural politics of legibility - Jia Jia's constant invocation of Seattle as a space makes the city legible for contemporary Chinese viewers in a number of significant ways. In conjuring the immigration-friendly story of visiting Seattle inspired by the movie, Jia Jia is actually quoting the original text, which has Meg Ryan take her romantic cues from repeatedly watching An Affair to Remember (Leo McCarey, 1956, Twentieth Century Fox). Deborah Kerr and Carey Grant's romantic epic was filmed on the French Riviera 
and in Villefranche-sur-mer before their climactic rendezvous at the top of the Empire State building in New York. This 1950s exemplar of the touring film provides Ryan's character with the inspiration to suggest the same rendezvous point to Tom Hanks, leading to Jia Jia's attempts to reach the popular landmark.

In these narrative patterns, cities and their iconic sites become characters in themselves. Through repeated incarnation in global hits, cities and landmarks can develop a kind of star persona, in the sense described by Richard Dyer, in which the meanings associated with a particular star are shaped by their previous appearances, both on and off-screen $(2004,2-3)$. New York and the Empire State building become associated with cinematic romance in An Affair to Remember and Sleepless in Seattle, and Seattle takes on the same romantic connotations for Jia Jia in Finding Mr. Right. Tang Wei as Jia Jia also carries her own star persona into the film text. Made famous by her role in Lust, Caution (Ang Lee, 2007), Tang is associated with romance, but also with illegality and even exile. China's State Administration of Radio and Television ordered a media ban on Tang, ostensibly due to the sexualized nature of her performance in Lust, Caution, though many critics have speculated that the ideological content of the film was to blame for her treatment. Tang spent the next two years in a kind of exile. Unable to find work in China, she enrolled at the University of Reading in the UK and performed Shakespearean plays. Her next film role was an English-speaking part in Late Autumn (Hangul, 2010, Boram Entertainment; Film Workshop), directed by Kim Tae-yong and shot in Seattle. This coproduction between South Korea, Hong Kong, China, and the US, brought Tang back to the cinema public in a narrative explicitly centered on travel, exile, and punishment. In this way, themes of travel, foreignness, illegality, and romance are apparent in Tang's global star persona, 
which also exhibits linguistic fluency. Tang's successful negotiation of overseas travel, work, and study, shape viewer expectations for her character Jia Jia.

Yet on her first attempt to get to the Empire State building, Jia Jia finds herself arrested due to a misunderstanding. Attempting to negotiate her release from prison while she is obviously pregnant with a rapidly expiring tourist visa, her love interest Frank coaches her to use the language of the romance film to pass the police interview. Invoking Meg Ryan's attempt to form a blended family with Tom Hank's character and his child in Sleepless in Seattle, she wins the sympathy of the police translator and negotiates her release. While the illegality of her character's situation mirrors Tang's own troubles with the Chinese government, her fluent use of the language of the romance film clears her character's path in the same way Tang's involvement with multi-lingual co-production films re-opened her path to working in China. The smooth elision of the kind of actual linguistic encounter and misunderstanding Dwyer observes in polyglot film genre is achieved by positioning the romance genre within the film narrative as universally meaningful, and hence as a mode of communication in itself.

The 'universal language' of genre conventions and star persona are a means of making differing geographical or cultural understandings and expectations legible for people from other places. The owners of the birth tourism company Happy Baby invoke this same shared language of cinema in their justification for their business strategy, arguing in a recent news report, "Bruce Lee was a birth tourism baby. Maybe we'll get another genius out of it!" [Berfield, (2015)]. In this way, a shared understanding of cinematic tropes and conventions can become a means of negotiating the geopolitical challenges of tourism as practice where the real and the reel become increasingly indistinguishable. The blurring of the reel and the real is particularly visible in 
northern Thailand where reports of Chinese tourists re-enacting scenes from the film Lost in Thailand canvass international media reports.

\section{Lost in Thailand}

The Chinese blockbuster hit, Lost in Thailand depicts Xu Lang and his rival business manager, Gao Bo, who compete for the rights to a renewable energy solution for which they need a shareholder's approval. Xu travels to Bangkok where he is introduced to Wang Bo, a professional pancake maker who imparts a new sense of the meaning of life to $\mathrm{Xu}$. Xu and Gao travel throughout Thailand humorously encountering local Thai residents. Film critics liken Xu's experience to that of contemporary urban Chinese professionals who experience corporate burn out from an intensely competitive workplace environment, long hours, and strained family dynamics. Depicting Thailand 'as simultaneously a commercial and spiritual destination' (Yang, 2015: 377), Lost in Thailand reflects an experience familiar to many urban Chinese professionals in that the drive for economic success is at odds with desires for human connection.

Lost in Thailand was the second highest grossing Chinese movie in 2012, and inspired a growing number of Chinese tourists to travel to Thailand. As one report explains, the 'hit 2012 Chinese comedy film, Lost in Thailand, boosted the image of a tourist paradise of Buddhist temples and beaches' (Reuters 2016). Patrick Brzeski argues that 'The scale of Lost in Thailand's success in the world's most populous country... makes a direct influence hard to deny' (2013). Thus, the film is largely credited with the development of tourism to many sites throughout Thailand which in 2016 welcomed nearly eight million Chinese tourists, nearly a 70 percent increase since 2014 (Coconuts Bangkok, 2016). While the economic impact of the growth of Chinese tourism to Thailand has been mostly welcomed, reports of uncomfortable encounters between Chinese tourists and Thai residents are widespread. 
These Sino-Thai host-guest encounters are mediated by the history of Sino-Thai relationships that exist within an atmosphere of Siamese nationalism and assimilation policies that have been in effect since the early $20^{\text {th }}$ century. Chinese economic power has intensified over the last century where today, approximately 15 percent of the population of Thailand claims Chinese descent. Thai citizens of Chinese descent control an estimated 90 percent of all investments in the industry sector and 50 percent of all investments in banking and finance (de Pablos \& Lytras, 2009, 206; Morita, 2003). Morita points out that this distribution of wealth has been highly concentrated for nearly a century, as 'By the 1930s, the Chinese constituted $85 \%$ of the commercial class and held in their hands 90\% of Siam's commerce and trade... Proassimilation policies made sense in the face of such dominance over the Siamese economy' (Morita, 2003, p. 487). Chinese economic influence in Thailand is a source of pride for some Chinese tourists. Lin Ju, a female Chinese tourist explained in an article in the South China Morning, that she was "proud of the 'hardworking Chinese in Thailand' who contributed so much to the economy back home at a time when China was yet to arrive as an economic powerhouse" [Farrell, (2016)]. Indeed, Chinese tourists frequently travel to northern Thailand to learn about their Teochew ancestors, many of whom fled to Thailand from an impoverished China in the early $20^{\text {th }}$ century. Lin Ju further explained how 'We have heard a lot about our ancestors migrating to Thailand, the lore of Chinese migration that are part of our childhood memories' (Farrell 2016). Recent critiques of Chinese influence in Thailand and the region more generally are mediated by the historical Sino-Thai political-economic relationship.

A cursory review of media headlines and social media in Thailand suggest an ambivalent and often uncomfortable relationship between Chinese tourists and Thai residents: 
Thai media has bristled with stories of misdemeanours by Chinese tourists. Some viral videos have featured gluttonous Chinese diners stacking their plates with prawns, an antiChinese rant by a Thai celebrity over queuing etiquette in a Korean airport, skylarking youngsters dressing up in Thai university uniforms, and a Chinese tourist drying her underwear at Chiang Mai airport. Belligerent, unruly, noisy and disrespectful are the most common adjectives used in Thailand when it comes to Chinese tourists (Farrell 2016). Recently, these critiques have been picked up in Chinese media, and as a result, in 2016 many Chinese nationals and would be tourists called for a boycott to Thailand. Many analysts blame the 30 percent drop in Chinese tourists to Chiang Mai on the boycott, reportedly the result of negative representations of Chinese tourists on social media. Consequently, many destinations in Chiang Mai are desperate to welcome back Chinese tourists. The Night Safari, a popular tourist destination in northern Thailand hung a sign near the entrance of the zoo that read "I love Chinese people" in Chinese and Thai in an effort to demonstrate their appreciation for Chinese tourists (Nancy, 2016). 


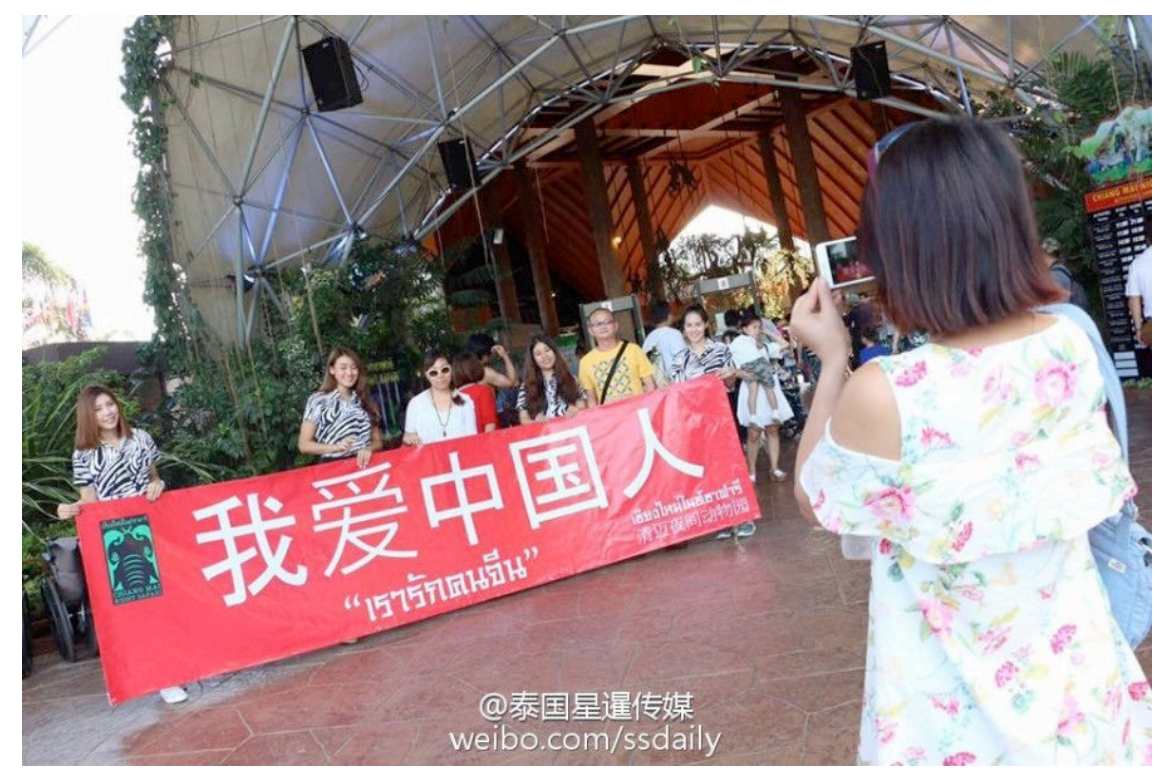

Figure 1. "I love Chinese people" banner at the Chiang Mai Zoo.

http://www.hubgold.com/2016/07/28/thailand-chiang-mai-i-love-china-banner/

These local efforts to reduce the impact of the Chinese travel boycott have been met by the national efforts of the Tourism Authority of Thailand (TAT), which has invited Chinese media to ameliorate any 'misunderstandings' about Thais' contempt for Chinese tourists (Coconuts Bangkok, 2016). The TAT governor, Yutthasak Supasorn made it clear that "Thai people actually welcome Chinese tourists because they bring a lot of revenue into Thailand" [Coconuts Bangkok, (2016)]. These sentiments were echoed by numerous high level corporate and government officials who warned Thais of the economic consequences of losing the Chinese market. In a seminar to the Foreign Trade Department, a representative told the audience, 'Do not miss out on opportunity. More Chinese will travel, and if they avoid Thailand and chose to visit other countries instead, Thailand will lose so much' (Coconuts Bangkok, 2016). These directives to Thai residents to welcome Chinese tourists are part of a broader geopolitical strategy to enhance Sino-Thai personal, economic, and trade relations. 
The Chinese government responded to these critiques in the 2013 publication of the Guide to Civilized Tourism and Travel which warns its citizens of conducting themselves inappropriately abroad: “Don't spit phlegm or gum, throw litter, urinate or defecate wherever you feel like it. Don't cough, sneeze or pick your nose or teeth in front of others" [Gilford, (2013)].

3. 不随地吐痰和口香糖, 不乱扔废弃物, 不随地大 小便，不在别人面前做出抠挖鼻孔、剔牙、咳嗽、打喷 德等失礼的举止。

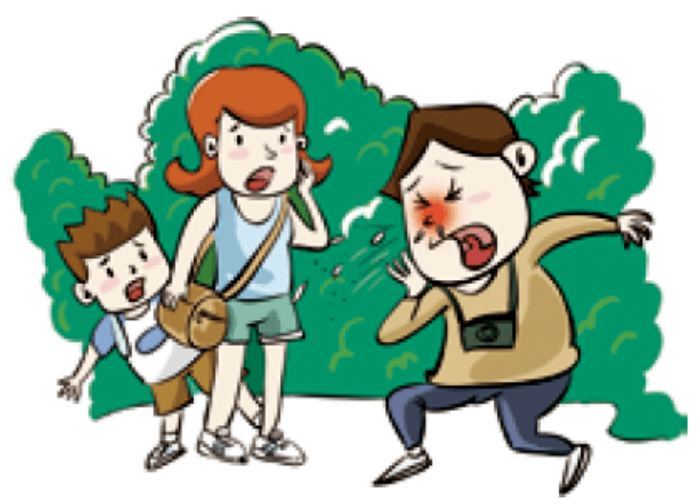

Figure 2. https://www.theatlantic.com/china/archive/2013/10/chinese-governmentpublishes-guide-on-how-to-avoid-being-a-terrible-tourist/280332/

Thailand has similarly responded with etiquette manuals in Mandarin that explain the customs and values of Thai people and give instructions for appropriate behaviour in museums, lavatory facilities, and while driving. These etiquette manuals reveal how tourism encounters are geopolitical sites of articulation that are significant for broader state building projects. Yang points out that what makes Lost in Thailand unique is 'that the spatial consumption typical of travel films acquires an alternative form here, one that does not fortify but rather undermines the imagination of Chinese power in a foreign land' (Yang, 2015: 377). As a result of this spatial 
consumption 'the newly emergent tourist discourse builds upon the organizational principles of holiday-themed films, and how this particular genre and style, at times, can enable apolitical encounters with the society's collective consciousness, while critiquing the limits and conditions of China's post-socialist reality from within' (Yang, 2015: 377).

Director Wang Baoqiang and the screenwriters of Lost in Thailand have extended the reach of Chinese motivated film tourism well beyond Thailand. The subsequent filming of Lost in Hong Kong and Lost in India have similarly received widespread acclaim from Chinese as well as international audiences:

In the wake of Lost in Thailand's record-setting performance in 2012, the northern Thai city of Chiang Mai, where the film was set, reported a sudden surge of Chinese tourists. While the issue is undoubtedly a chicken-or-egg phenomenon — was Lost in Thailand so popular because it tapped the curiosity and wanderlust of China's emerging middle class, or did middle-class Chinese movie fans swarm to Thailand because they wanted to recreate their own Lost in Thailand adventure? (both, probably) — a similar pattern has already cropped up around Lost in Hong Kong. (Brzeski, 2003)

Indeed, three days after the release of Lost in Hong Kong, and its record setting weekend sales after its September 2015 debut, the Shanghai travel agency, CTrip sold out of its Lost in Hong Kong themed travel package including tours to sites depicted in the film (Brzeski, 2003). Hong Kong tourism officials hoped that the film would have a similar impact on tourism numbers as Lost in Thailand had on tourism to Thailand, where in the first quarter after the film's release, Chinese tourism numbers increased 93 percent.

The most recent film in the series, Lost in India (Danao Tianzhu), was developed in an effort to increase the number of Chinese tourists to India as well as an explicit geopolitical and 
soft power strategy (Nye, 2005). A recent report in Jing Daily explains, 'While chilly political relations and negative stereotypes have prevented India from cashing in on China's outbound tourism boom, the South Asian country hopes that a new set of film deals and warming ties will change that in the years to come' (Flora 2016). Collaboration between film industries and governments to soften strained geopolitical relations is notable for how it reflects the increasingly critical role of popular geopolitical discourses and everyday geopolitical encounters. Highlighting the role of Chinese film-induced tourism to Thailand in the broader constellation of Sino-Thai geopolitical relations opens up everyday practices of tourism and film as new registers of the political.

\section{Conclusion}

Through our analysis of three popular Chinese films depicting Chinese tourists abroad, we have illustrated how film motivated tourism has become an increasingly significant crosscultural touchstone that blurs boundaries between the real and reel in geopolitical discourse and practice. This deepening entanglement is significant for the ways in which it creates new geopolitical discourses of travel that have broader implications for interpersonal, as well as international relations. Scenes from internationally based Chinese films are frequently imputed by Chinese tourists in their host countries where they interact with host community members. These interactions are often at least in part based on directives from the films. Additionally, the multiple layers of signification (e.g. Sleepless in Seattle and Beyonce in Finding Mr. Right) are indicative for the ways in which film motivated tourism calls upon the technologies of simulacra to make meaning of tourist encounters. Reports of these sometimes awkward engagements canvass popular media reports of Chinese tourists abroad. This analysis indicates how images 
and narratives of tourism are constructed in contemporary popular Chinese cinema and how cinematic representations of tourism are influencing actual tourist flows.

Recent Chinese film narratives frequently present tourism as not only desirable, but also as an easily negotiated practice, provided one performs as a 'good' tourist. These discourses are reflected in tourist etiquette manuals that are aimed at limiting cultural dissonance in tourism encounters and the corollary cultural stereotypes that are often challenged or reinforced through such interactions. Yet examining the popular discourse around cinema-motivated touristic practices in Japan, Thailand, and the US, we can see continuing inter-cultural conflicts arise through tourism, both informed by and informing geopolitical imaginaries of place.

Film plays a powerfully mediating role in the blending of the real and reel in ways that encourage travel aspirations while muting the challenges of intercultural communication and understanding. In this way, tourist encounters as they are enacted in film become significant reference points for travel motivations in everyday life. At the same time, discourses of travelrelated problems feed back into film narratives and are then resolved in the happy endings common to classical narrative cinema, re-creating an image of the touristic encounter as something inevitably understandable. These findings are particularly timely for emerging work by interdisciplinary scholars on the broader implications of popular geopolitical discourse and everyday tourism encounters. Future work in this vein would benefit from more thorough ethnographic research on international tourism encounters, especially in Asia, one of the fastest growing tourism markets globally. 


\section{References}

Arlt, W. (2016) 'China's Outbound Travelers Are Moving On To Change The World Of Tourism In 2016', Forbes: Asia [online]

https:/www.forbes.com/sites/profdrwolfganggarlt/2016/01/01/2016-chinas-outbound-tourismmoving-on-to-change-the-world-of-tourism/\#19c328944b33.

Bao, W. (2009) 'In search of a 'cinematic Esperanto': exhibiting wartime Chongqing cinema in global context', Journal of Chinese Cinemas 3: 2, pp. 135-147.

Bao, W. (2009) 'In search of a 'cinematic Esperanto': exhibiting wartime Chongqing cinema in global context', Journal of Chinese Cinemas 3: 2, pp. 135-147.

Berfield, S. (2015) 'Chinese Maternity Tourists and the Business of Being Born American', Bloomberg Business Week, [online]. https://www.bloomberg.com/news/articles/2015-0513/chinese-maternity-tourists-and-the-business-of-being-born-american Box office mojo (2017) [online] http://www.boxofficemojo.com/intl/china/yearly/?yr=2008\&p=.htm.

Bruno, G. (2002) Atlas of Emotion: Journeys in Art, Architecture, and Film, Verso, London. Brzeski, P. (2013) 'Chinese Hit Comedy 'Lost in Thailand' Generating Mixed Returns for Thai Economy', The Hollywood Reporter [online] http://www.hollywoodreporter.com/news/chinesehit-comedy-lost-thailand-420445.

Carlin. D. (1997) 'The Cultural ‘Traumascape': Look Both Ways, Railways Accidents and Trauma', Senses of Cinema, 45 [online] http://sensesofcinema.com/2007/australian-cinema45/look-both-ways/\#18.

Carter, E. (2010) 'Introduction', in Carter, E. (Ed.) Béla Bàlazs: Early Film Theory. Translated by Robert Livingston. Berghan Books, New York, pp. xv-xlvii. 
Chu, J. (2010) Cosmologies of Credit: Transnational Mobility and the Politics of Destination in China, Duke University Press, New York.

Coconuts Bangkok. (2016) 'TAT desperate to bring Chinese tourists back after they boycott Thailand', Coconuts Bangkok [online] https://coconuts.co/bangkok/news/tat-desperate-bringchinese-tourists-back-after-they-boycott-thailand.

Cohen, L. (2013) 'Emerald City cameo in Chinese lm bringing tourists to Seattle.' Komonews [online] http:// www.komonews.com/news/local/Big-screen-cameo-in-popular-Chinese- lmbringing- tourists-to-Seattle-238318171.html.

Dwyer, T. (2005) 'Universally Speaking: Lost in Translation \& Polyglot Cinema', Linguistica Antwerpiensia New Series 4, pp. 295-310.

Dyer, R. (2004) Heavenly Bodies; Film Stars and Society, Routledge, London.

Farrell, J. (2016) 'What's Really Behind Thailand's Hostility to Chinese Tourists?' South China Post [online] http:/www.scmp.com/week-asia/society/article/2058256/whats-really-behindthailands-hostility-chinese-tourists.

Flora, L. (2015) 'Will More Chinese Tourists Get 'Lost in India' Thanks to Joint Film Productions?', Jing Daily [online] https://jingdaily.com/will-more-chinese-tourists-get-lost-inindia-thanks-to-joint-film-productions/.

Frey, M. (2010) 'Cultural problems of classical film theory: Béla Balázs, 'universal language’ and the birth of national cinema', Screen 51:4, pp. 324-340.

Fung Global Retail and Tech. (2016) ‘Chinese Shoppers Carry Spending Momentum’ [online] https://www.fungglobalretailtech.com/research/global-chinese-shoppers-carry-spendingmomentum-2016. 
Gilford, G. (2013) 'Chinese Government Publishes Guide on How to Avoid Being a Terrible Tourist', The Atlantic [online] https:/www.theatlantic.com/china/archive/2013/10/chinesegovernment-publishes-guide-on-how-to-avoid-being-a-terrible-tourist/280332/.

GEE, J. P. 2014. How to do discourse analysis: A toolkit. Routledge, New York. Hansen, M. (1985) 'Universal Language and Democratic Culture: Myths of Origin in Early American Cinema', in Meindl, D. and Horlacher F. (Eds.) Myth and Enlightenment in American Literature: In Honor of Hans-Joachim Lang, Universitätsbund Erlangen-Nürnberg, Nürnberg, pp. $321-51$.

Hansen, M. (2000) 'The mass production of the senses: classical cinema as vernacular modernism', in Gledhill, C. and Williams, L. (Eds.), Reinventing Film Studies, Arnold, London, pp. 332-350.

Huat, C. (2012) Structure, Audience, and Soft Power in East Asian Pop Culture, Hong Kong University Press, Hong Kong.

Iwabuchi, K. (Ed.), (2004) Feeling Asian Modernities: Transnational Consumption of Japanese TV Dramas, Hong Kong University Press, Hong Kong. Iwabuchi, K. et al (Eds), (2004) Rogue Flows Trans-Asian Cultural Traffic, Hong Kong University Press, Hong Kong.

Jameson, F. The Geopolitical Aesthetic: Cinema and Space in the World System, Indiana University Press, Indianapolis.

JNTO (2015) 国籍別 / 目的別 訪日外客数（確定值) 2003-2015 [online] http://www.jnto.go.jp/jpn/statistics/tourists_2015.np.pdf JNTO (2017) 国籍/月別訪日外客数 (2003年～2017年) [online] http://www.jnto.go.jp/jpn/statistics/since2003_tourists.pdf 
Kirby, L. (1997) Parallel Tracks: The Railroad and Silent Cinema. Duke University Press, Durham.

Lewis, T. et al. (2016) Telemodernities: Television and Transforming Lives in Asia, Duke University Press, Durham.

Lu, R. (2014) ‘Look Who’s Walking: Chinese Birth Tourism Goes Stateside’, Foreign Policy [online] http://foreignpolicy.com/2014/04/25/look-whos-walking-chinese-birth-tourism-goesstateside/

Lukinbeal, C. (2004) 'The map that proceeds the territory: an introduction to essays in cinematic geography', Geojournal, Vol. 59, pp. 247-251.

Lukinbeal, C. (2012) ““On location” filming in San Diego County from 1958-2005: How a cinematic landscape is formed through incorporative tasks and represented through mapped inscriptions', Annals of the Association of American Geographers, Vol 102, pp. 171-190. METI近畿経済産業局(2015)関西を訪れた外国人旅行者等に対する生声アンケート調査」報 告書 [online] http://www.kansai.meti.go.jp/7kikaku/26report/150511_namagoe_report.pdf MLIT (2017)訪日外国人の消費動向 訪日外国人消費動向調査結果及び分析H29 [online] http://www.mlit.go.jp/common/001182004.pdf

Mostafanezhad, M. and Promburom, T. (2016) 'Lost in Thailand: the popular geopolitics of filminduced tourism in northern Thailand', Social \& Cultural Geography, pp. 1-21. Nancy. (2016) 'Thailand Chiang Mai I Love China Banner', Hub Gold [online] http://www.hubgold.com/2016/07/28/thailand-chiang-mai-i-love-china-banner/. Neale, S. (1980) Genre. British Film Institute, London. Neale, S. (1990) 'Questions of genre', in Boyd-Barrett, O. and Newbold, C. (Eds.) Approaches to Media: A Reader, Arnold: London, pp. 460-472. 
Nikkei Business (2017)中国人観光客がもう「爆買い」をしない理由[online]

http://business.nikkeibp.co.jp/atcl/opinion/16/011000037/013100005/.

Nyiri, P. (2006) Scenic Spots: Chinese Tourism, the State, and Cultural Authority, University of Washington Press, Seattle.

Nyiri, P. (2010) Mobility and Cultural Authority in Contemporary China, University of Washington Press, Seattle.

Ong, A. and Nonini. (1997) Ungrounded Empires: The Cultural Politics of Modern Chinese Transnationalism, Routledge, New York.

Osburg, J. (2013) Anxious Wealth: Money and Morality Among China's New Rich, Stanford University Press, Stanford.

Otmazgin, N. (2008) 'Contesting Soft Power: Japanese Popular Culture in East and Southeast Asia', International Relations of the Asia-Pacific, Vol. 8 No.1, pp. 73-101.

NYE, J. 2005. Soft Power: The Means to Success in World Politics, Public Affairs: New York.

NYE, J. S., JR. 2004. Soft Power and American Foreign Policy. Political Science Quarterly,119, 255-270.

Paris, N. (2015) 'Thailand issues good behaviour manual for Chinese tourists', The Telegraph

[online] http://www.telegraph.co.uk/travel/destinations/asia/thailand/articles/Thailand-issuesgood-behaviour-manual-for-Chinese-tourists.

Pease, R. (2009) 'Korean Pop Music in China: Nationalism, Authenticity, and Gender', in Berry, C., Liscutin, N., and Mackintosh, J. (Eds.), Cultural Studies and Cultural Industries in Northeast Asia What a Difference a Region Makes, Hong Kong University Press, Hong Kong. 
Power, M. and Crampton, A. (2005) 'Reel geopolitics: cinemato-graphing political space', Geopolitics, Vol. 10, pp. 193-203.

Reuters. (2016) 'Thailand Still Golden for Chinese Tourists Despite Zika Fears', Fortune Magazine [online] http://fortune.com/2016/10/01/thailand-tourism-zika/.

Schivelbusch, W. (1986) The Railway Journey: The Industrialization of Time and Space in the 19th Century, University of California Press, Berkeley and Los Angeles.

Sheehan, M. (2015) ‘Born In The USA: Why Chinese ‘Birth Tourism’ Is Booming In California', Huffington Post [online] http://www.huffingtonpost.com/2015/05/01/china-us-birthtourism_n_7187180.html.

Shyong, F. (2016) 'Why birth tourism from China persists even as US Officials crack down', $L A$ Times [online] http://www.latimes.com/local/lanow/la-me-ln-birth-tourism-persists-20161220story.html.

Song, G., and Lee, T. (2010) ‘Consumption, Class Formation and Sexuality: Reading Men’s Lifestyle Magazines in China', The China Journal, no. 64 (July): pp.159.

Sun, W. (2002) Leaving China: Media, Migration, and Transnational Imagination, Rowman \& Littlefield Publishers: London.

Wang Y. (2015) 'Explosive Shopping Not the Only Reason Chinese People Visit Japan, Study Shows', Japan Times [online] http://www.japantimes.co.jp/news/2015/12/04/national/explosiveshopping-not-reason-chinese-people-visit-japan-survey-shows/.

Yang, W. (2015) 'Lost in Thailand: Travel metaphors in contemporary Chinese comedy', East Asian Journal of Popular Culture, Vol. 1, pp. 377-388. 